\title{
Platelet Aggregation by Group B Streptococci
}

\author{
By YUKIO USUI, * YUKIO OHSHIMA AND KOSAKU YOSHIDA \\ Department of Microbiology, St Marianna University School of Medicine, 2-16-1, Sugao, \\ Miyamaye-ku, Kawasaki 213, Japan
}

(Received 29 October 1986; revised 20 January 1987)

\begin{abstract}
Forty-six strains of group B streptococci (GBS), including various serotypes and nonserotypable strains, were tested for their ability to induce platelet aggregation in human plateletrich plasma; four strains, all belonging to type III, showed a positive reaction. The characteristics of the reaction were investigated in these four positive strains. Aggregation was dependent on the ratio of bacteria to platelets, being maximal at a ratio of $4 \cdot 3$. Platelet aggregation was inhibited by EDTA $(100 \%$ inhibition at $3.1 \mathrm{~mm})$, indomethacin $(100 \%$ inhibition at $10 \mathrm{mM})$, acetylsalicylic acid $(93-100 \%$ inhibition at $5.0 \mathrm{~mm})$ and quinacrine $(100 \%$ inhibition at $0.25 \mathrm{mM}$ ). Thus the reaction was cation-dependent and required cyclooxygenase activity. Assays for cytosolic lactate dehydrogenase did not indicate platelet lysis. GBS induced the release of $\left[{ }^{3} \mathrm{H}\right]$ serotonin, which was maximal $(68-78 \%)$ at $10 \mathrm{~min}$ after the reaction was started. Experiments with gel-filtered platelets suggested that GBS-induced platelet aggregation required both fibrinogen and heat-resistant $\left(56^{\circ} \mathrm{C}, 30 \mathrm{~min}\right)$ serum factors. Type-specific antisera prevented the platelet aggregation activity of heat-killed bacteria, but not of live bacteria. Trypsin digestion of the bacterial cells caused an almost complete loss of the platelet aggregation activity.
\end{abstract}

\section{INTRODUCTION}

Platelets are known to respond to various aggregation agents such as ADP, arachidonate, collagen and thrombin (Holmsen et al., 1969). Also, platelet aggregation is induced by viruses (Jerushalmy et al., 1961), antigen-antibody complexes (Henson, 1970), lipopolysaccharides (Morrison et al., 1978) and bacteria (Clawson \& White, 1971). Bacteria causing platelet aggregation include staphylococci (Hawiger et al., 1972, 1979), streptococci (Kurpiewski et al., 1983) and listeria (Czuprynski \& Balish, 1981), as well as several species of Gram-negative bacteria. The relation between aggregation and infection has been discussed (Czuprynski \& Balish, 1981; Hawiger et al., 1979; Kurpiewski et al., 1983).

We recently showed that a type III strain of group B streptococci (GBS) exhibiting positive clumping factor (CF) reaction induced intravascular coagulation in mice (Usui et al., 1986), suggesting the possible induction of disseminated intravascular coagulation (DIC). Since a decrease of platelet count is generally recognized as one of the diagnostic criteria of DIC, it is of interest to examine the ability of the strain to cause platelet aggregation in vitro. However, little is known about GBS-platelet interaction except for the recent data reported by Wood \& Gray (1986).

In this paper, we report some properties of platelet aggregation induced by strains of GBS.

\section{METHODS}

Bacterial strains. GBS were isolated from clinical specimens at the Clinical Laboratory, St Marianna University School of Medicine Hospital. The organisms were bacitracin-resistant and were identified as GBS by both the

Abbreviations: ASA, acetylsalicylic acid; CF, clumping factor; DPO, 2,5-diphenyloxazole; GAS, group A streptococci; GBS, group B streptococci; GFP, gel-filtered platelets; PPP, platelet-poor plasma; PRP, plateletrich plasma. 
microprecipitin test (Swift et al., 1943) and serological grouping by the Phadebact-Streptococcus test (Pharmacia), which is based on the method of Christensen et al., (1973). A strain of group A streptococci (GAS) obtained from the clinical specimens was used as a control.

Culture. The bacteria were grown for approximately $20 \mathrm{~h}$ in Todd-Hewitt broth (Difco). They were harvested by centrifugation $\left(7000 \mathrm{~g}, 4{ }^{\circ} \mathrm{C}, 30 \mathrm{~min}\right)$, washed three times with $0.01 \mathrm{M}$-phosphate buffered saline (PBS), pH 7.4, and resuspended in the same buffer. Bacterial numbers were estimated by nephelometry and reference to a standard curve of light scattering versus viable count. Bacteria were killed by heating at $60^{\circ} \mathrm{C}$ for 10 min before use unless otherwise stated.

Chemicals. 5-Hydroxy[G- $\left.{ }^{3} \mathrm{H}\right]$ tryptamine creatinine sulphate $\left(19.6 \mathrm{Ci} \mathrm{mmol}^{-1} ; 725 \cdot 2 \mathrm{GBq} \mathrm{mmol}^{-1}\right)$ was from Amersham, human fibrinogen (grade L) from AB KABI, $\mathrm{Na}_{2}$ EDTA, indomethacin, acetylsalicylic acid (ASA), trypsin and 2,5-diphenyloxazole (DPO) from Wako Pure Chemical Industries, quinacrine dihydrochloride and NADH (disodium salt) from Sigma, Triton X-100 from Nakarai Chemicals, and Sepharose-2B from Pharmacia. Other chemicals were all reagent grade.

Preparation of human platelets. Human blood was collected into $0 \cdot 1$ vol. $3.8 \%(w / v)$ sodium citrate from drug-free donors and was used as a source of platelets. Only plastic tubes and pipettes were used. Citrated blood was gently mixed, then centrifuged at $150 \mathrm{~g}$ for $10 \mathrm{~min}$ at room temperature. Platelet-rich plasma (PRP) was removed, and the platelet concentration was adjusted to $300000 \mu \mathrm{l}^{-1}$ by addition of platelet-poor plasma (PPP) obtained by centrifuging the PRP at $1640 \mathrm{~g}$ for $10 \mathrm{~min}$. Platelet numbers were counted as described by Brecher \& Cronkite (1950). PRP was stored in capped plastic tubes at room temperature until used, and experiments were completed within $4 \mathrm{~h}$. Gel-filtered platelets (GFP) were prepared by passing $2.0 \mathrm{ml}$ portions of the PRP preparation through a Sepharose-2B column according to the method of Timmons \& Hawiger (1978). In the case of GFP, numbers of platelets were adjusted to $300000 \mu 1^{-1}$ by the addition of HEPES buffer, $\mathrm{pH} \mathrm{7.35}$. For the preparation of serum, blood drawn from the volunteers was kept for $1 \mathrm{~h}$ at $37^{\circ} \mathrm{C}$ before transfer to $4^{\circ} \mathrm{C}$ to facilitate clot contraction. Blood cells were then removed by centrifugation at $1500 \mathrm{~g}$ for $20 \mathrm{~min}$, and serum was obtained by means of a sterile pipette.

Platelet aggregation. A tetra-channel aggregometer (NKK Hema Tracer 1 model Pat-4A PAT-4M) was used to measure platelet aggregation. In each experiment, PPP was used to adjust the instrument to $100 \%$ transmission to represent $100 \%$ aggregation. A mixture of $200 \mu \mathrm{l}$ of either PRP or GFP, and $22 \mu \mathrm{l} 0.01 \mathrm{M}-\mathrm{PBS}, \mathrm{pH} 7 \cdot 4$, was used to represent $0 \%$ transmission (zero aggregation). In the actual experiments, $200 \mu$ l PRP or GFP was added to a cuvette, which was placed in the aggregometer with stirring at 1000 r.p.m., and allowed to warm to $37^{\circ} \mathrm{C}$. Then $22 \mu \mathrm{l}$ of the bacterial suspension was added, and the density of the bacterial suspension was readjusted to zero. Platelet aggregation was observed for at least $10 \mathrm{~min}$. To test whether the platelet preparation was normal and adequate for the reaction to proceed, ADP was added to a final concentration of $1.5 \mu \mathrm{M}$.

In the inhibition experiments, indomethacin, ASA, quinacrine or EDTA was preincubated with the PRP for $10 \mathrm{~min}$ at room temperature before transfer to the $37^{\circ} \mathrm{C}$ environment in the aggregometer. To observe the effects of plasma components, the GFP $(0.2 \mathrm{ml})$ were kept for $10 \mathrm{~min}$ at room temperature together with one of several plasma components $(40 \mu \mathrm{l})$. When necessary, serum was heated at $56^{\circ} \mathrm{C}$ for $30 \mathrm{~min}$ and the precipitates formed were discarded after centrifugation.

Release of serotonin and lactate dehydrogenase. Serotonin within platelets was labelled by incubation of PRP with $1 \mu \mathrm{Ci}(37 \mathrm{kBq})\left[{ }^{3} \mathrm{H}\right] \mathrm{serotonin}$ for $30 \mathrm{~min}$ at room temperature. After the addition of bacterial suspension, aggregation was recorded as usual. From a separate tube containing a larger volume of the same mixture in a $37^{\circ} \mathrm{C}$ water bath, $300 \mu \mathrm{l}$ portions were removed at intervals of approximately $1 \mathrm{~min}$ and added to $50 \mu \mathrm{l} 933 \mathrm{mM}$ formaldehyde containing $51 \mathrm{mM}$-EDTA in $1.5 \mathrm{ml}$ centrifuge tubes held in ice. The tube was centrifuged at $12000 \mathrm{~g}$ for $2 \mathrm{~min}$. Duplicate $50 \mu \mathrm{l}$ samples were removed and added to $5 \mathrm{ml}$ scintillation fluid ( 1 vol. Triton X-100 and 2 vols toluene containing $0.4 \%, w / v, D P O)$, and radioactivity was measured by an Aloka Liquid Scintillation System LSL-753. Total radioactivity in the samples was determined by using uncentrifuged controls. Release of radiolabelled serotonin was calculated as described by Holmsen \& Dangelmaier (1977).

Lactate dehydrogenase released from platelets during these experiments was determined by the method reported by Bergmeyer et al. (1965). A solution of Triton X-100 was used to lyse the platelets to determine the total amount of intracellular lactate dehydrogenase.

Assay of CF activity. This was done by the method reported previously (Usui et al., 1982). Briefly, a bacterial suspension containing about $8.5 \times 10^{9}$ c.f.u. $\mathrm{ml}^{-1}$ and a fibrinogen solution $\left(3 \mathrm{mg} \mathrm{ml} \mathrm{m}^{-1}\right)$ were prepared immediately before the assay. Then the bacterial suspension was mixed on glass slides with equal volumes of serial twofold dilutions of fibrinogen solution. Within $2 \mathrm{~min}$ of the reaction, the reciprocal of the maximum dilution causing clumping of the bacteria was recorded.

Trypsin digestion of bacteria. Heat-killed $\left(60^{\circ} \mathrm{C}\right.$ for $\left.10 \mathrm{~min}\right)$ bacteria were adjusted to $1.0 \times 10^{9}$ c.f.u. $\mathrm{ml}^{-1}$ in $0.01 \mathrm{M}-\mathrm{PBS}, \mathrm{pH} 7.4$ and incubated with trypsin at a concentration of $0.01 \mathrm{mg} \mathrm{ml}^{-1}$ at $37^{\circ} \mathrm{C}$ for the required time. After incubation, bacteria were washed three times with $0.01 \mathrm{M}-\mathrm{PBS}, \mathrm{pH} \mathrm{7.4}$, before resuspension to $9.0 \times 10^{9}$ c.f.u. $\mathrm{ml}^{-1}$.

Preparation of rabbit antisera. GBS strains were cultured in Todd-Hewitt broth at $37^{\circ} \mathrm{C}$ for $24 \mathrm{~h}$, then the 
organisms were washed once by centrifugation and resuspended in $0.01 \mathrm{M}-\mathrm{PBS}, \mathrm{pH} 7 \cdot 4$. The organisms were treated with formalin and then the turbidity was adjusted by nephelometry to $\mathrm{OD}_{430}=0.5$, which corresponded to $2 \cdot 1-2.4 \times 10^{8}$ c.f.u. $\mathrm{ml}^{-1}$. Quantities of $0.2 \mathrm{ml}$ were injected intravenously into rabbits on three successive days during the first week. In the second week, the vaccine was increased to $0.5 \mathrm{ml}$; thereafter, $1.0 \mathrm{ml}$ was injected on three successive days in each week for one month. Two weeks after the final immunization the rabbits were exsanguinated, and the sera were separated. The sera obtained were pre-absorbed with type la, Ib, Ic, and II organisms to eliminate the reaction with group antigens on the cells. The pooled pre-absorbed serum had an aggiutination titre against the homologous strain of 1280 .

Inhibition of the platelet aggregation acitivity with type-specific antisera. Equal volumes of the bacterial suspension and type III pre-absorbed sera were mixed, incubated at $37^{\circ} \mathrm{C}$ for the required time, and then subjected to the platelet aggregation assay.

\section{RESULTS}

Platelet aggregation activity in GBS. When 46 strains ( 7 type Ia, 1 type Ib, 3 type Ic, 10 type II, 22 type III, and 3 non-typable strains) were tested for reactivity with platelets, four strains, all belonging to type III and positive for the CF reaction (Usui et al., 1982), were also positive for platelet aggregation within $10 \mathrm{~min}$. The values of platelet aggregation induced by the four strains, SMU-11, 50, 53 and 56 , were $80,86,82$ and $90 \%$, respectively. The strains that were negative for platelet aggregation were all CF-negative.

Effects of the ratio between the counts of bacteria and platelets on platelet aggregation. When the bacterial concentration exceeded $8 \cdot 1 \times 10^{7}$ c.f.u. $\mathrm{ml}^{-1}$, a significant increase in the aggregative response developed, with a maximum at about $1.3 \times 10^{9}$ c.f.u. $\mathrm{ml}^{-1}$ (final concentration). This optimal cell number corresponded to a bacterial c.f.u./platelets ratio of 4.3 and was similar with all the strains used in these experiments (Fig. 1).

Serotonin release. The release of serotonin from platelets was detected after 2 min incubation with GBS. With each of the GBS strains, after 10 min incubation (when aggregation was mostly complete) $68-78 \%$ of the intracellular serotonin was released from the platelets (Table 1, Fig. 2). Similarly, $70.6 \%$ of the serotonin was released from platelets after $10 \mathrm{~min}$ incubation with a GAS strain (Table 1).

Lactate dehydrogenase release. To determine whether platelets were lysed by the action of GBS, the activity of lactate dehydrogenase was measured $10 \mathrm{~min}$ after commencement of the aggregation experiment. The platelets contained the expected amount of the enzyme (1002 U), whereas the supernatant fluids from the PBS control and the four GBS bacteria/platelet mixtures had similar levels, 113 and 181-256 U, respectively (Table 1). In the case of the GAS strain, $249 \mathrm{U}$ of enzyme was detected (Table 1).

Effects of EDTA, ASA, indomethacin and quinacrine on the platelet aggregation induced by GBS. Platelet aggregation by the four strains of GBS was totally inhibited by $3.1 \mathrm{mM}$-EDTA but not by $0.67 \mathrm{~mm}$-EDTA (Table 2). Also two cyclooxygenase inhibitors and one phospholipase $\mathrm{A}_{2}$ inhibitor (Roth \& Majerus, 1975; Vargaftig, 1977) were examined for their ability to inhibit platelet aggregation by GBS. ASA $(0.1 \mathrm{mM})$ inhibited aggregation by $78-89 \%$ whereas quinacrine $(0.025 \mathrm{mM})$ gave $74-86 \%$ inhibition, depending on the strain used. Higher doses of the reagents, $10 \mathrm{~mm}$-ASA or $0.25 \mathrm{~mm}$-quinacrine, completely inhibited the aggregation induced by the four strains of bacteria tested, as did $10 \mathrm{~mm}$-indomethacin (Table 2).

Requirement for plasma components. To test the effects of plasma components on GBS-induced platelet aggregation, separate lots of GFP were supplemented with one of the following components: human fibrinogen, heated serum $\left(56^{\circ} \mathrm{C}, 30 \mathrm{~min}\right)$ or PPP. In the experiments with GBS strains, GFP alone or GFP supplemented with fibrinogen were not sufficient for complete platelet aggregation. However, in the case of the GAS strain, supplementation of GFP with fibrinogen was sufficient for aggregation to occur (Table 3). Supplementation with heated serum was also ineffective for platelet aggregation by GBS. Only supplementation with PPP or a mixture of fibrinogen and heated serum achieved complete platelet aggregation in the case of GBS (Table 3). 


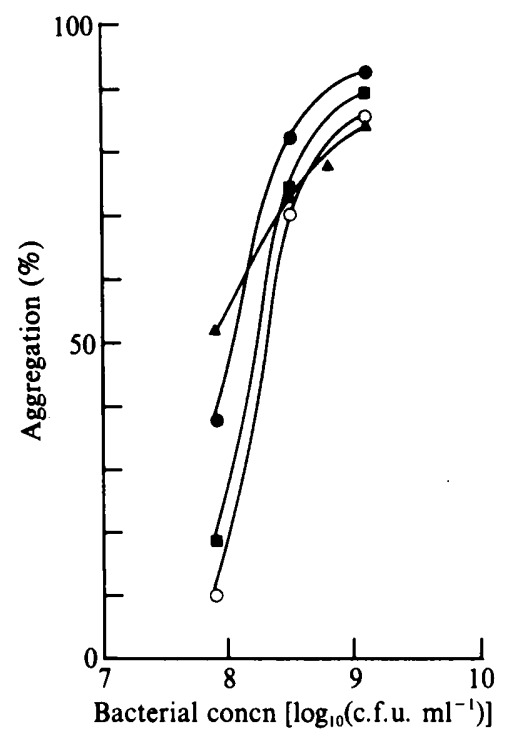

Fig. 1.

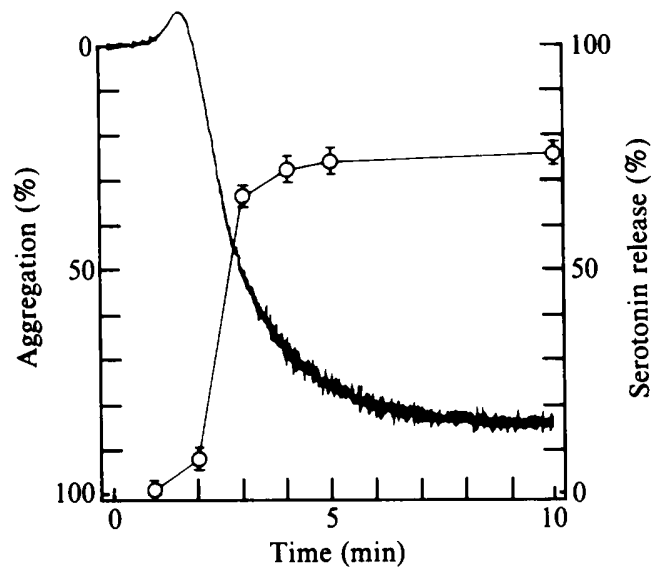

Fig. 2.

Fig. 1. Percentage aggregation of platelets in PRP upon exposure to different concentrations of four strains of GBS during a 10 min incubation. $\square$, SMU-11; , SMU-50; O, SMU-53; $\Delta$, SMU-56.

Fig. 2. Release of serotonin ( $\mathrm{O}-\mathrm{O}$; bars indicate range) and percentage aggregation of human platelets exposed to GBS strain SMU-56 (spiked line) over a $10 \mathrm{~min}$ incubation. Bacterial numbers (final concentration) were $1.3 \times 10^{9}$ c.f.u. $\mathrm{ml}^{-1}$.

Table 1. Release of serotonin and lactate dehydrogenase ( $L D H)$ during platelet aggregation by four strains of $G B S$ and one strain of $G A S$

The results are means \pm range of two determinations. Bacterial numbers (final concentration) were

$1.2-1.4 \times 10^{9}$ c.f.u. $\mathrm{ml}^{-1}$ for the GBS strains and $9.5 \times 10^{8}$ c.f.u. $\mathrm{ml}^{-1}$ for the GAS strain.

$\begin{array}{lccc}\text { Strain } & \text { Serotonin release }(\%) & \text { LDH }\left(\mathrm{U} \mathrm{ml}^{-1}\right)^{*} & \text { Platelet aggregatio } \\ \text { GBS } & & & \\ \text { SMU-11 } & 75.6 \pm 2.3 & 224.4 \pm 82.7 & 80 \pm 2 \\ \text { SMU-50 } & 78.3 \pm 1.6 & 181.9 \pm 30.7 & 86 \pm 3 \\ \text { SMU-53 } & 68.3 \pm 2.5 & 215.0 \pm 30.7 & 82 \pm 3 \\ \text { SMU-56 } & 76.6 \pm 1.7 & 256.4 \pm 8.8 & 90 \pm 3 \\ \text { GAS } & 70.6 \pm 1.9 & 248.9 \pm 19.1 & 75 \pm 3 \\ \text { SMU-054 } & & \end{array}$

* LDH was assayed after $10 \mathrm{~min}$ of the commencement of the reaction. Control values: saline (negative control), 113.4 \pm 9.7; Triton X-100 (positive control), 1001.7 $\pm 19 \cdot 6$.

Effects of type-specific antisera on the aggregation ability of GBS. When undiluted type-specific antisera were preincubated for $10 \mathrm{~min}$ with heat-killed bacteria of strain SMU-50 or SMU-56 before contact with PRP, platelet aggregation was mostly prevented. After 30 min incubation, the aggregation induced by these strains was completely inhibited (Table 4). Platelet aggregation induced by strain SMU-50 was inhibited to $0,1,2.5,8$ and $54 \%$ of the control aggregation (after $5 \mathrm{~min}$ of the reaction) by undiluted, 10-fold, 20-fold, 40-fold and 80-fold diluted antisera, respectively (Fig. 3). However, when living bacteria were used in place of heatkilled bacteria, type-specific antisera were not inhibitory even after prolonged incubation (65 min) (Table 4).

Effects of trypsin digestion of GBS on their platelet aggregation ability and CF activity and the agglutination titre of type-specific antisera. Bacteria of the four GBS strains positive for platelet aggregation were incubated with trypsin solution for several minutes and tested for their 


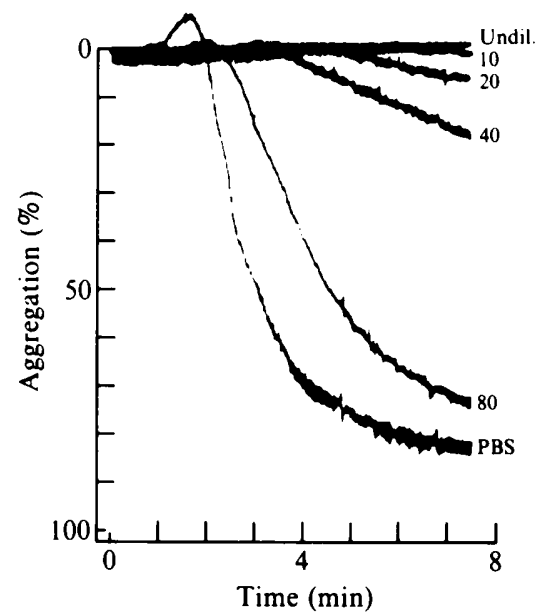

Fig. 3. Effects of different doses of type-specific antisera on the platelet-aggregating activity of GBS strain SMU-56. The numbers next to the traces indicate the dilution (fold) of the antiserum. Undil., undiluted antiserum; PBS, 0.01 M-PBS (pH 7.4) (control). Bacterial numbers (final concentration) were $1.3 \times 10^{9}$ c.f.u. $\mathrm{ml}^{-1}$.

Table 2. Effects of EDTA, ASA, quinacrine and indomethacin on the platelet aggregation induced by GBS strain SMU-50

The results are means \pm range of two determinations. Bacterial numbers (final concentration) were $1.1 \times 10^{9} \mathrm{c} . \mathrm{f}$.u. $\mathrm{ml}^{-1}$. The following concentrations of reagents were also tested and completely inhibited platelet aggregation: EDTA, 3.1 and $10 \mathrm{mM}$; ASA, 5 and $10 \mathrm{~mm}$; quinacrine, 0.25 and $1 \mathrm{~mm}$. Similar results were obtained with the other three GBS strains tested, except that 5 mM-ASA inhibited aggregation by about $95 \%$ in the case of strains SMU-53 and 56.

$\begin{array}{lccc}\text { Reagent } & \text { Concn }(\mathrm{mM}) & \text { Platelet aggregation (\%) } & \text { Inhibition (\%) } \\ \text { EDTA } & 0 \cdot 67 & 50 \pm 2 & 41 \\ \text { ASA } & 0 \cdot 1 & 9 \pm 1 & 89 \\ \text { Quinacrine } & 0 \cdot 025 & 22 \pm 2 & 74 \\ \text { lndomethacin } & 10 & 0 & 100 \\ \text { PBS (control) } & & 85 \pm 3 & 0\end{array}$

Table 3. Effects of supplementation with plasma components on aggregation of GFP by four strains of $G B S$ and one strain of $G A S$

The results are means \pm range of two determinations. Bacterial numbers (final concentration) were $1.0-1.4 \times 10^{9}$ c.f.u. $\mathrm{ml}^{-1}$ for the GBS strains and $9.5 \times 10^{8}$ c.f.u. $\mathrm{ml}^{-1}$ for the GAS strain.

\begin{tabular}{|c|c|c|c|c|}
\hline \multirow[b]{3}{*}{ Strain } & \multicolumn{4}{|c|}{ Platelet aggregation $(\%)$} \\
\hline & \multicolumn{3}{|c|}{ GFP supplemented with } & \multirow[b]{2}{*}{ GFP alone } \\
\hline & Fib.* & Fib. ${ }^{*}+$ htd serum $\dagger$ & PPP & \\
\hline \multicolumn{5}{|l|}{ GBS } \\
\hline SMU-11 & $7 \pm 1$ & $70 \pm 2$ & $73 \pm 2$ & 0 \\
\hline SMU-50 & $9 \pm 1$ & $65 \pm 2$ & $74 \pm 2$ & 0 \\
\hline SMU-53 & $7 \pm 1$ & $70 \pm 2$ & $77 \pm 3$ & 0 \\
\hline SMU-56 & $8 \pm 1$ & $68 \pm 2$ & $80 \pm 3$ & 0 \\
\hline GAS & & & & \\
\hline SMU-054 & $55 \pm 2$ & $70 \pm 2$ & $75 \pm 2$ & $3 \pm 1$ \\
\hline
\end{tabular}


Table 4. Effects of type-specific antisera on the platelet-aggregating ability of two strains of GBS

The results are means \pm range of two determinations. Bacterial numbers (final concentration) were $1.2 \times 10^{9}$ c.f.u. $\mathrm{ml}^{-1}$ for $\mathrm{SMU}-50$ and $0.8 \times 10^{9}$ c.f.u. $\mathrm{ml}^{-1}$ for SMU-56.

\begin{tabular}{|c|c|c|c|c|}
\hline Strain & $\begin{array}{l}\text { Addition of } \\
\text { antiserum* }\end{array}$ & $\begin{array}{l}\text { Incubation } \\
\text { time (min) }\end{array}$ & $\begin{array}{l}\text { Aggregation } \\
(\%)\end{array}$ & $\begin{array}{c}\text { Inhibition } \\
(\%)\end{array}$ \\
\hline \multicolumn{5}{|l|}{ SMU-50 } \\
\hline heat-killed & + & 10 & $6 \pm 1$ & 92.9 \\
\hline heat-killed & + & 30 & 0 & 100 \\
\hline heat-killed & - & 10 & $85 \pm 2$ & 0 \\
\hline living & + & 10 & $70 \pm 3$ & $12 \cdot 5$ \\
\hline living & + & 65 & $70 \pm 3$ & $12 \cdot 5$ \\
\hline living & - & 10 & $80 \pm 3$ & 0 \\
\hline \multicolumn{5}{|l|}{ SMU-56 } \\
\hline heat-killed & + & 10 & $15 \pm 1$ & $81 \cdot 9$ \\
\hline heat-killed & + & 30 & $\overline{0}$ & 100 \\
\hline heat-killed & - & 10 & $62 \pm 2$ & 0 \\
\hline living & + & 10 & $80 \pm 2$ & 0 \\
\hline living & + & 65 & $79 \pm 2$ & $1 \cdot 3$ \\
\hline living & - & 10 & $80 \pm 2$ & 0 \\
\hline
\end{tabular}

aggregation abilities. In the case of strain SMU-50 $\left(9.0 \times 10^{8}\right.$ c.f.u. $\mathrm{ml}^{-1}$, final concentration), the platelet aggregation activity decreased from $85 \%$ to $5 \%$ after $5 \mathrm{~min}$ trypsin digestion. The $\mathrm{CF}$ assay revealed that 5 min trypsin digestion was enough to remove the $\mathrm{CF}$ activity on the cell surface. In contrast, the type antigen, measured by agglutination titre using anti-type III serum, was not lost by the trypsin treatment, although the titre decreased to one-fourth (titre 320 ) of the control value (titre 1280). A similar trend was observed with the three other strains.

\section{DISCUSSION}

GBS-induced platelet aggregation was reported by Wood \& Gray (1986) to be dependent on the GBS/platelet ratio, with an optimal ratio of 1.5 . In the present experiments, maximum aggregation was observed at a ratio of about 4.3 for all the strains tested, although the same procedure as reported by Wood \& Gray (1986) was used. This difference may be due to variation in platelets from different individuals.

The presence of EDTA, ASA or quinacrine has been reported to inhibit GAS-induced platelet aggregation (Kurpiewski et al., 1983). Also, bacterium-induced platelet aggregation has been reported to require plasma components such as fibrinogen (Des Prez et al., 1980; Kurpiewski et al., 1983), immunoglobulin G (Des Prez et al., 1980; Hawiger et al., 1979), or complement system components (Hawiger et al., 1972; Sheth et al., 1980; Skerl et al., 1981). The results described above indicate that GBS-induced platelet aggregation requires both cations and an intact arachidonate pathway, as well as the presence of fibrinogen and heat-resistant $\left(56^{\circ} \mathrm{C}, 30 \mathrm{~min}\right)$ serum components in the reaction mixture. These properties are similar to those of GASinduced platelet aggregation (Kurpiewski et al., 1983), except the requirement for heat-resistant serum components in GBS. In addition, participation of a bacteriolytic substance such as haemolysin seemed unlikely in the GBS-platelet reaction.

Fibrinogen receptor is present on some species of bacteria (Kronvall et al., 1979; Schönbeck et al., 1981; Yoshida et al., 1979). In staphylococci, fibrinogen receptor has long been called CF because of its effects when bacteria are mixed with fibrinogen or plasma (Much, 1908). We have found a similar material in GBS and tentatively called it CF (Usui et al., 1982). The rate of distribution of CF-positive strains among GBS was relatively low (4 out of 76; unpublished data). Interestingly, the strains positive for platelet aggregation were all positive for CF activity, and aggregation-negative strains were all negative for CF activity. Thus, the CF of GBS could participate in the reaction since fibrinogen is required for platelet aggregation to proceed. However, it is not known how these plasma factors participate in the platelet aggregation by GBS. 
As inhibition of GBS-induced platelet aggregation by type-specific rabbit antisera was reported by Wood \& Gray (1986), we did similar experiments. Although results which supported their data were obtained when heat-killed bacteria were used, little or no inhibition was observed when live bacteria were used. The fact that type-specific antisera inhibit the reaction retrospectively supports the idea that the type III antigen itself is responsible for the aggregation phenomenon. However, only four out of 22 strains of type III GBS showed a positive reaction and a crude type III antigen extract failed to induce platelet aggregation (unpublished data). Furthermore, although the platelet-aggregating activity was easily destroyed by a brief treatment with trypsin, the net amount of the type III antigen on the cell surface (measured by agglutination titre) was not significantly affected by the treatment, unlike the case of CF activity. These data suggest that another factor (or factors) different from type III antigen is (are) associated with the phenomenon of platelet aggregation by GBS, although the basis of the different effects of the antisera on heat-killed and live bacteria needs to be elucidated.

The extraction and purification of the substance inducing this phenomenon are in progress in our laboratory.

We thank Dr M. Yamamoto, Department of Laboratory Medicine, St Marianna University School of Medicine, for use of the aggregometer.

\section{REFERENCES}

Bergmeyer, H. U., Bernt, E. \& Hess, B. (1965). Lactic dehydrogenase. In Methods of Enzymatic Analysis, pp. 736-741. Edited by H. U. Bergmeyer. New York: Academic Press.

Brecher, G. \& Cronkite, E. P. (1950). Morphology and enumeration of human blood platelets. Journal of Applied Physiology 3, 365-377.

Christensen, P., Kahlmeter, G., Jonsson, S. \& Kronvall, G. (1973). New method for the serological grouping of streptococci with specific antibodies absorbed to protein-A-containing staphylococci. Infection and Immunity 7, 881-885.

Clawson, C. C. \& White, J. G. (1971). Platelet interaction with bacteria. I. Reaction phases and effects of inhibitors. American Journal of Pathology 65, 367-380.

CZUPRYNSKI, C. J. \& BaLISH, E. (1981). Interaction of rat platelets with Listeria monocytogenes. Infection and Immunity 33, 103-108.

Des Prez, R. M., Steckley, S., Stroud, R. M. \& HAWIGER, J. (1980). Interaction of Histoplasma capsulatum with human platelets. Journal of Infectious Diseases 142, 32-39.

Hawiger, J., Marney, S. R., Colley, D. G. \& Des Prez, R. M. (1972). Complement-dependent platelet injury by staphylococcal protein A. Journal of Experimental Medicine 136, 68-80.

Hawiger, J., Steckley, S., Hammond, D., Cheng, C., Timmons, S., Glick, A. D. \& Des Prez, R. M. (1979). Staphylococci-induced human platelet injury mediated by protein $A$ and immunoglobulin $G$ Fc fragment receptor. Journal of Clinical Investigation 64, 931-937.

Henson, P. M. (1970). Mechanisms of release of constituents from rabbit platelets by antigen-antibody complexes and complement. Journal of Immunology 105, 476-489.

Holmsen, H. \& Dangelmaier, C. A. S. (1977). Adenine nucleotide metabolism of blood platelets. $X$. Formaldehyde stops centrifugation-induced secretion after A23187-stimulation and causes breakdown of metabolic ATP. Biochimica et biophysica acta 497, 46-61.

Holmsen, H., DAY, H. J. \& Stormorken, H. (1969). The blood platelet release reaction. Scandinavian Journal of Haematology (Supplement) 8, 3-26.

Jerushalmy, Z., KohN, A. \& DE VRIES, A. (1961). Interaction of myxoviruses with human blood platelets in vitro. Proceedings of the Society for Experimental Biology and Medicine 106, 462-464.

Kronvall, G., Schönbeck, C. \& MYHRE, E. (1979). Fibrinogen binding structure in $\beta$-hemolytic streptococci group A, C, and G. Acta pathologica et microbiologica scandinavica 87, 303-310.

Kurpiewsi, G. E., Forrester, L. J., Campbell, B. J. \& BARReTT, J. T. (1983). Platelet aggregation by Streptococcus pyogenes. Infection and Immunity 39, 704-708.

Morrison, D. C., Kline, L. F., OAdes, Z. G. \& Henson, P. M. (1978). Mechanisms of lipopolysaccharide-initiated rabbit platelet responses: alternative complement pathway dependence of the lytic response. Infection and Immunity 20, 744-751.

MuCH, H. (1908). Über eine Vorstufe des Fibrinfermentes in Kulturen von Stafylokokkus Aureus. Biochemische Zeitschrift 14, 143-155.

Roth, G. J. \& MAJERUS, P. W. (1975). The mechanism of the effect of aspirin on human platelets. I. Acetylation of a particulate fraction protein. Journal of Clinical Investigation 56, 624-632.

SCHÖNBECK, C., BJORCK, L. \& KRONVAlL, G. (1981). Receptors for fibrinogen and aggregated $\beta_{2}$-microglobulin detected in strains of group B streptococci. Infection and Immunity 31, 856-861.

Sheth, N. K., Kurup, V. P. \& Barron, B. A. (1980). The role of Aspergillus fumigatus antigens in blood coagulation and platelet function. Microbios 28, 9196.

Skerl, K. G., Calderone, R. A. \& Sreevalsan, T. (1981). Platelet interactions with Candida albicans. Infection and Immunity 34, 938-943.

Swift, H. F., Wilson, A. T. \& Lancefield, R. C. 
(1943). Typing group A hemolytic streptococci by Mprecipitin reactions in capillary pipettes. Journal of Experimental Medicine 78, 127-133.

TIMmONS, S. \& HAWIGER, J. (1978). Separation of human platelets from plasma proteins including factor VIII by a combined albumin gradient-gel filtration method using HEPES buffer. Thrombosis Research 12, 297-306.

Usui, Y., Yoshida, K. \& SAN Clemente, C. L. (1982). Characterization of partially purified group B streptococcal clumping factor. Zentralblatt für Bakteriologie, Microbiologie und Hygiene (I Abt. Orig. A) 252, 299-309.

Usui, Y., Ichiman, Y., Yoshida, K. \& Oikawa, K. (1986). Possible induction of disseminated intravascular coagulation in the mouse by group B strepto- coccal clumping factor. British Journal of Experimental Pathology 67, 629-635.

VARGAFTIG, B. B. (1977). Carragenan and thrombin trigger prostaglandin synthetase-independent aggregation of rabbit platelets: inhibition by phospholipase $\mathrm{A}_{2}$ inhibitors. Journal of Pharmacy and Pharmacology 29, 222-228.

WoOd, E. G. \& GraY, B. M. (1986). Type-specific antibody prevents platelet aggregation induced by group B streptococci type III. Journal of Laboratory and Clinical Medicine 107, 322-326.

Yoshida, K., TAKahashi, M., OHTOMO, T., Usui, Y. \& NARIKAWA, S. (1979). Factors causing the clumping reaction of streptococcal strains with human plasma. Journal of Infectious Diseases 139, 242-245. 